\title{
Biogas production from organic waste and biomass - fundamentals and current situation
}

\author{
Sản xuất khí sinh học tùu sinh khối và rác thải hũu co-nguyên lý và hiện trạng. \\ Review paper
}

Dornack, Christina*

Technical University of Cottbus, Germany, Siemens-Halske-Ring, 03046 Cottbus, Germany

\begin{abstract}
The use of renewable waste for bioenergy production is in discussion because of the concurrence to the food or animal feed. The treatment of organic waste is necessary in order to keep clean the environment. The combination of those proposals, the waste utilization and the production of renewable energy can be combined with several techniques. In Vietnam the energy demand will increase rapidly in the next years, because a lot of people do not have access to electricity. The development of power sources is limited mainly to large central power plants using hydropower and traditional fossil fuels. So in the country there exists a considerable potential for sustainable energy sources like biomass and residues. The biogas potential is large due to the high livestock population. There are more than 30 million animals in farms, mostly pigs, cattle, and water buffalo. There is a high potential for biogas utilization. Biogas production is economic in small and in big plants, so household biogas digesters are one opportunity for production of renewable energy in small villages or cities with a high livestock population. The advantage of anaerobic treatment of organic waste is the work in closed loops. The treatment of organic waste and the utilization of digested sludge from wastewater treatment plants are samples for the circulation of materials after use. The remaining materials can be used in the natural circulation process, because the nutrients such as nitrogen, phosphorous and carbon, and also trace elements remain in the digested matter. In biogas plants a huge variety of substrates can be used. The adaption of biogas technology to the special conditions of the substrates, the increase of the prices for energy, the aim to replace fossil energies with renewable energies will be forced in the next years.
\end{abstract}

Việc sử dụng chất thải có thể tái tạo được để sản xuất năng luợng sinh học là vấn đề còn đang được thảo luận vì sư cạnh tranh với thức ăn hoăc thức ăn cho động vật. Việc xủ lý các chất thải hưu co là cần thiết để giữ sạch môi truờng. Sư kết hợp của các đề xuất đó, tận dưng các chất thải và sản xuất năng luợng tái tạo có thể có thể đuợc kết hợp với một số kỹ thuật. Ơ Việt Nam, nhu cầu năng luợng sẽ tăng lên nhanh chóng trong những năm tiếp theo, bởi vì rất nhiều người vẫn chưa có điện sủ dụng. Sự phát triển của các nguồn năng lượng chỉ giới hạn chủ yếu là các nhà máy điện lớn trung tâm sử dụng thủy điện và các nhiên liệu hóa thach truyền thống. Vì vậy, trong nuớc tồn tại tiềm năng đáng kể cho các nguồn năng lương bền vũng nhu sinh khối và nhũng nguồn khác. Tiềm năng khi sinh học lớn do quần thể động vật nuôi rất lớn. Có hơn 30 triệu động vật trong trang trại, chủ yếu là lợn, bò, trâu nuớc. Tiềm năng sủ dụng khí sinh học rất cao. Sản xuất khi sinh học rất có hiệu quả kinh tế trong các nhà máy nhỏ và lớn, do đó, các thiết bị phản ưng tạo khí sinh học ở các hộ gia đình là một co hội để sản xuất năng luợng tái tạo trong các thành phố hay làng mạc nhỏ với số luợng lón các gia súc được chăn nuôi. Uu điểm của việc xủ lý ky khí các chất thải hữu co là làm việc trong vòng khép kín. Việc xử lý các chất thải hũu co và sử dụng bùn phân hủy tù các nhà máy xử lý nuớc thải là các ví dụ cho việc tuần hoàn các vật chất sau khi sử dụng. Các vật chất còn lại có thể được sủ dụng trong quá trình tuần hoàn tư nhiên, vì các chất dinh dương nhu phốt pho, nitơ và carbon, và cả các nguyên tố vi luợng vẫn tồn tại trong nguyên liệu đã phân hủy. Trong các nhà máy khi sinh học, rất nhiều loại chất nền có thể được sử dụng. Sự cải tiến công nghệ sản xuất khi sinh học theo các điều kiện đặc biệt của các chất nền, sư gia tăng của giá năng lượng, muc đỉch thay thế nguồn năng luợng hóa thạch bằng năng luợng tái tạo sẽ là bắt buộc trong nhũng năm tới.

Keywords: biogas, organic waste, waste generation, digested sludge, fertlizer, emissions 


\section{Introduction}

The energy content in waste can be utilized either by biological conversion of organic matter to biogas or to biofuel like bio-ethanol, by combustion of waste, or by producing a solid fuel for usage in power plants or cement kilns.

The biogas or biofuel production from organic waste is an economic process already in small, but also in and in big plants. The process technology can be easily adopted in dependence of the composition of the substrates and the water content of the waste.

The use of renewable for bioenergy production is in discussion because of the concurrence to the food or animal feed. The treatment of organic waste is necessary in order to keep clean the environment. The combination of those proposals, the waste utilization and the production of renewable energy can be combined with several techniques.

The treatment of organic waste material like livestock dung and the usage of sewage sludge are examples on how materials which are produced by nature can be brought back into the material circle of nature after successful treatment. The main objective of an anaerobic treatment of biomass is to use the energetic potential of the organic material by fermenting the contained carbon into methane. Nutrients and trace elements remain in the fermentation residue and can be returned to the natural material circle. A variety of different substrates is used in biogas plants. Figure 1 shows which substrates can be used in biogas plants.

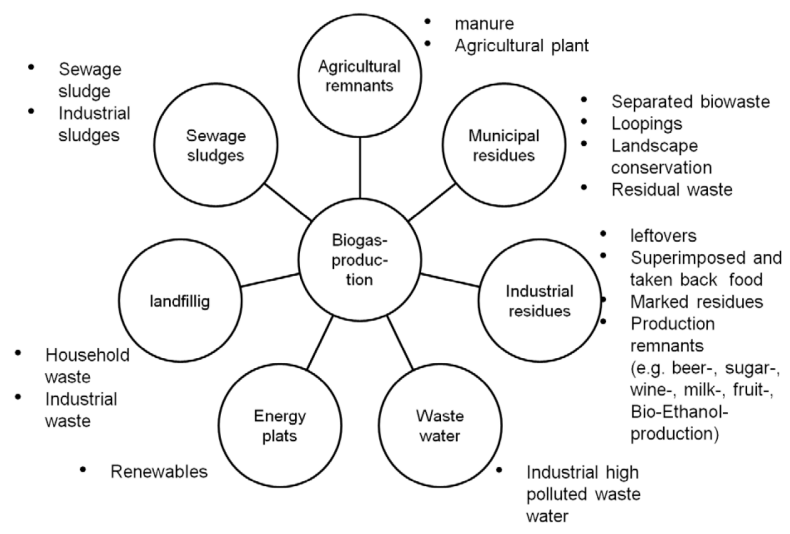

Figure 1. Substrates for biogas production (Scholwin, 2006, modified)

Today in Germany, due to funding-policy based measures substrates that are difficult to degrade under anaerobic conditions can be successfully applied in biogas plants. There are various techniques regarding substrate storage, substrate pretreatment and substrate input and biogas plants are built and operated at different sizes. Plants of agricultural holdings usually have an installed capacity of about $150 \mathrm{~kW}$ or less; the big biogas parks have an installed capacity of $20 \mathrm{MW}$.

Depending on size and location of a plant different techniques for biogas processing, biogas storage and biogas usage are applied. The usage of solid or liquid fermenta- tion residues depends on the local conditions and legal requirements. Small agricultural plants use the fermentation residue directly as soil fertilizer. Industrial plants mostly have a downstream treatment plant for fermentation residues, which realizes material recycling as well as the thermal utilization of fermentation residues. Figure 2 shows the technological procedure of biogas plants.

\section{Input materials and biogas potential}

\subsection{Germany}

$97 \%$ of all biogas plants belong to agricultural holdings. As they use manure and excrements from their own livestock farming there is no need for logistic chain of substrate purchase. Further, renewable raw materials, which are grown specifically for biogas production, will be used as mono- or co-substrate. According to a survey carried out in 2006 in Bavaria, where more than $40 \%$ of all biogas plants of Germany are located, $75 \%$ of plants ferment renewable raw materials like corn, grass and silage from corn or grass in combination with manure - mainly cow manure (Biogas Handbook Bavaria, 2010). Figure 2 shows the distribution of substrates.

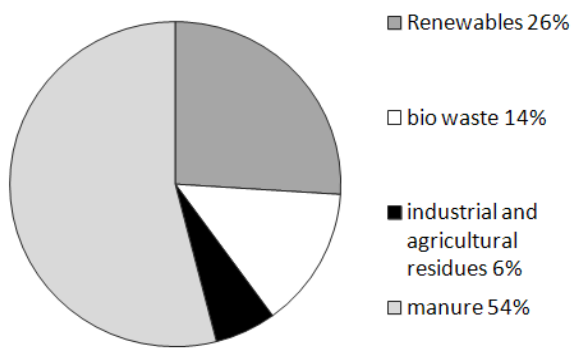

Figure 2. Mass flow in biogas plants in Germany (Thrän et al., 2009, modified)

Biowaste fermentation plants receive their substrate from the communal and commercial collection of waste material. Separately collected biowaste from households contains following fractions: kitchen and food waste, garden waste, paper, cardboard, other waste material (e.g. foreign matters such as textiles, plastics, glass, metals, composites) and a fine fraction (usually $<8 \mathrm{~mm}$ ). The proportional composition of separately collected biowaste can only be determined by a sorting analysis (see Table 1).

Table 1. Composition of separately collected biowaste from households (according to Schnapke, 2011) including data from INTECUS (2002) and Raussen et al. (2009)

\begin{tabular}{lcc} 
Biowaste fraction & $\begin{array}{c}\text { Mean value } \\
{[\mathbf{M . 0} \%]}\end{array}$ & $\begin{array}{c}\text { Range of values } \\
{[\mathbf{M . - \% ]}}\end{array}$ \\
\hline Kitchen waste & 24.4 & $7.7-68.0$ \\
Yard Waste & 55.4 & $3.7-91.5$ \\
Paper/Cardboard & 5.4 & $0.2-14.4$ \\
Other & 4.8 & $0.5-21.1$ \\
Fine fraction & 20.9 & $7.9-27.0$
\end{tabular}

According to Fricke et al. (2003) the fraction „others“ contains on average $57 \%$ plastics, $9 \%$ glass, $6 \%$ metals, 
$28 \%$ other materials. The fraction of plastics varies between $44 \%$ and $88 \%$.

Depending on the composition of biowaste up to $85 \%$ of the organic material can be degraded.

The collection of biowaste is done separately in every household. Due to its hygienic brisance biowaste is collected weekly (Stadtmüller, 2004). Following biowaste is transported from the collection point to a treatment plant.

\subsection{Vietnam}

More than 40,000 household biogas digesters with a volume between 1 to $50 \mathrm{~m}^{3}$ have been installed in rural areas in Vietnam in 2002 (Vietnam Country report, 2007), there was an increase of the number to 40,000 biogas plants in 2006 (Man et al., 2006).

The biogas potential in Vietnam is large, because the livestock population was increasing in the last years up to 30 million animals, mostly pigs, cattle, and water buffalo (see Table 2). A major problem for the increase of the biogas utilization is the lack of large-scale poultry or pig farms. The livestock sector is done in household farms with stocks of 5 to 20 animals (Man et al., 2006).

Table 2. Biomass and biogas potential in Vietnam (Man, T.D., et al., 2006, Dornack, 2010)

\begin{tabular}{lcc} 
Biomass potential & $\begin{array}{c}\text { Mio. Tons } \\
\text { / year }\end{array}$ & $\begin{array}{c}\text { Biogas potential } \\
\text { [Mio. m } \text { mear] }^{3} \text { year }\end{array}$ \\
\hline Pig dung & 25.7 & 800 \\
Cattle dung & 20.2 & 500 \\
Buffalo dung & 16.0 & 900 \\
Municipal solid waste & 6.4 & 640
\end{tabular}

That means, that the biogas utilization can cover about $18.000 \mathrm{Gwh} / \mathrm{a}$.

In urban centers, like Hanoi, the utilization of biowaste is efficient for the use for biogas production. In the city of Hanoi about 790,000 Mg waste were generated in 2006 (JICA, Hanoi Urenco, 2006), in Ho Chi Minh City the amount of approximately $1.9 \mathrm{Mio} . \mathrm{Mg}$ of waste can be generated (Man et al., 2006). About $340 \mathrm{~kg} /$ person and year came up. $1.9 \mathrm{Mg}$ of bio-waste can generate about 80 $-140 \mathrm{~m}^{3}$ of biogas. Depending on the substrate composition and the technique of anaerobic digestion the methane content is about 55-60\%. [Kern M., Raussen T., 2009].

The energy consumption in Vietnam between 2000 and 2009 increased from $300 \mathrm{kWh} / \mathrm{a}$ per capita to $900 \mathrm{kWh} / \mathrm{a}$ per capita (WKO, 2012). 91 million inhabitants have an energy demand of approximately $82,000 \mathrm{GWh} / \mathrm{a}$. The actual percentage of non-fossil energy in sum is about $4 \%$ in Vietnam. The production of biogas energy with the dates of table 2 could cover about $20 \%$ of the energy demand in Vietnam. So biogas has a high potential for renewable energy production.

In Vietnam exist a high number of industries with organic residues like sugar industry, cassava processing factories, fruit, export canned food, beer and refreshment industries. All these residues can be used for biogas utilization. Furthermore there is a biogas potential in domestic and urban solid waste landfills.

\section{Process operation of biogas produc- tion}

\subsection{Distinction of biogas techniques}

Principally it can be divided between different fermentation systems as shown in Figure 3.

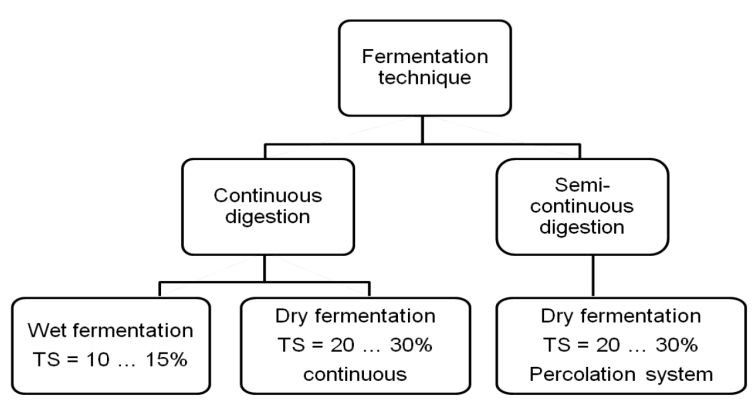

Figure 3: Overview of fermentation techniques after Lootsma, a. und Raussen, T. (2008)

\subsubsection{Dry and wet fermentation}

It is usually divide between dry and wet fermentation. However this is technically misleading as the microbiological process is always happening in the aqueous phase. Compared to wet fermentation in dry fermentation substrates are stackable but not pumpable. This depends on the viscosity of the input material. During microbiological transformation processes in the fermenters dry matter will be degraded and water is developing. Therefore the dry matter content of input substrate can be more than $30 \%$. Dry fermentation techniques have been optimised for the utilization of energy crops like maize or rape. Further input substrates suitable for these kinds of technology are: household waste, commercial waste, biowaste and agricultural residues such as solid dung, harvest residues, landscape conservation material and roadside greenery (Schüsseler, 2004).

Dry fermentation is mostly done single-stage in either plug flow fermenters or fully mixed digesters. Dry fermentation systems are less susceptible to foreign matters. That is why they are increasingly used for the fermentation of biowaste and residues. Because of the consistency of input substrates special transport techniques (e.g. slurry pump) are necessary (Schüsseler, 2004), (Scholwin, Gattermann, 2005).

For wet fermentation biogenic substrates with high humidity such as manure, sewage sludge and slop are suitable. In general wet fermentation is done in fully mixed single or double-stage digesters. The material transport and mixing within the fermenter is very easy because of the pumpability of substrates. Due to the high water content of substrates bigger fermenter volumes are necessary. The removal of unwanted matters needs to be done in 
advance of fermentation. Furthermore the fermentation residue must be drained (Fricke, Franke, 2002).

\subsubsection{Single and multi-stage systems}

Biogas plants can be operated single or multi-stage, whereas multi-stage systems can be either one step or two step fermentation processes (Figure 4). In one-stage fermentation systems all microbiological steps of degradation take place in one digester at the same time. But the milieu conditions are not at optimum for all microorganisms included in the process. There might be longer retention times needed in single-stage systems (federal environmental agency, 1999), (Fricke und Franke, 2002). Easy degradable substrates can be problematic because organic acid accumulation leads to process instability.

In multi-stage processes hydrolysis and acidogenesis are separated from acetogenesis and methanogenesis and process conditions can be adapted according to the requirements of microorganisms (Fricke und Franke, 2002). The spatial separation has the advantage of a better process stability and higher degradation rates can be achieved (Weiland, 2001). A disadvantage is the installation expenditure.

\subsubsection{Mesophilic and thermophilic processes}

Anaerobic degradation processes can be efficiently realised in mesophilic and thermophilic temperature range. The choice of temperature range influences the composition of microbiological flora and thereby the gas development rates. In general, with similar hydraulic retention times high temperatures lead to higher gas yields and degradation rates. But higher energy expenditure is needed to ensure the thermophilic conditions within the fermenter. As thermophilic methane producers have shorter generation times than mesophilic methane producers shorter hydraulic retention times can be realised compared to mesophilic proceedings.

The advantages of mesophilic and thermophilic operation of biogas plants are listed in the following table 3 (Kaltschmitt, 2009).

Table 3. Advantages of mesophilic and thermophilic operation of biogas plants (Kaltschmidt, 2009)

\section{Mesophilic proceeding}

Lower water vapour content of biogas

Less energy is needed to heat fermenters

High variety of microorganisms, therefore higher process stability

Due to lower $\mathrm{CO}_{2}$ solubility in the liquid and therefore lower $\mathrm{CO}_{2}$ content of biogas

\section{Thermophilic proceeding}

Higher growth rates

Lower solubility of oxygen in the substrate, therefore fast development of anaerobic conditions

Better killing of pathogen germs

Reduction of sludge volume

\section{Shorter retention times}

Most biogas plants are operated at mesophilic range between $35^{\circ} \mathrm{C}$ and $40^{\circ} \mathrm{C}$. The thermophilic temperature optimum is between $52^{\circ} \mathrm{C}$ and $57^{\circ} \mathrm{C}$.

\subsection{Preparation for anaerobic Treatment}

Reflecting on the substrates only biowaste and residual wastes needs to have an intensive pre-treatment in general. The objective of pre-treatment of biowaste before anaerobic processing is mainly the removal of unwanted matter, the comminution and homogenization of material. The volume flow is reduced by the amount of unwanted matter, which is removed from the input material and will not be treated in anaerobic fermenter (e.g. minerals, plastics). Technical separation processes have a high but not a $100 \%$ selectivity and separation rate. The treatment steps and aggregates for biowaste and residual waste need to be adapted according to the plant specific conditions.

A comminution of biowaste and residual waste but also for renewable raw materials, yard waste and agricultural residues is necessary to prepare the substrates for an efficient fermentation process. The comminution leads to the enlargement of the specific surface area and improves the water absorbency. Mixing and homogenizing of substrates is reasonable especially if the consistency of substrates is varying. Furthermore it leads to a faster degradation due to improved transportation processes.

\subsection{Microbiological fundamentals}

The anaerobic degradation proceeds in four steps according to Figure 4.

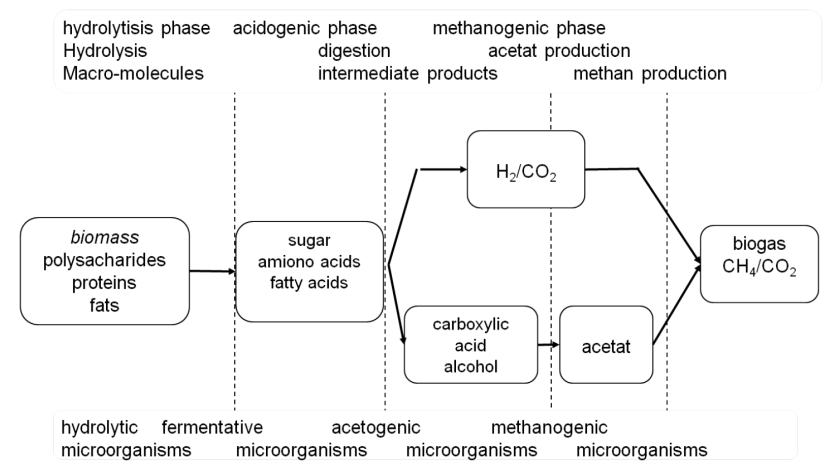

Figure 4. Schematically overview of anaerobic digestion of organic substrates (Weiland, 2003)

\subsubsection{Hydrolysis and Acidogenesis}

During hydrolysis the substrate (lipids, carbohydrates and proteins) is transferred into water soluble, low-molecular compounds by enzymes. This step is time limiting for the degradation of solid matter because material such as cellulose und lignin is only poorly or even not degradable during anaerobic fermentation. If the substrate contains many easy degradable carbohydrates such as starch or glycogen, a fast acid development will occur. Fats are hydrolyzed into glycerine, fatty acids and alcohol by extra cellular lipases and phospholipases. At temperatures $>$ $20^{\circ} \mathrm{C}$ fats are fully, but slowly hydrolyzed. The hydrolysis of proteins is very complex compared to other substance 
groups. The hydrolysis rate is lower than for carbohydrates and often lower than for fats (Bischofsberger et. al, 2004). Fermentational bacteria transfer sugar, alcohols, fatty acids and amino acids developed during hydrolysis into organic acids. The concentration of intermediary bound hydrogen determines the variety of fermentation products: low hydrogen concentrations lead to an intensified production of $\mathrm{CO}_{2}, \mathrm{H}_{2}$ und acetate, whereas high $\mathrm{pH}$ values cause the development of reduced end products such as propionate and butyrate.

\subsubsection{Acetogenesis and Methanogenesis}

The acetogenic bacteria use the intermediate products from acidogenesis to produce acetate, $\mathrm{CO}_{2}$ and $\mathrm{H}_{2}$. The growth rate of acetogenic bacteria is inhibited by high hydrogen concentrations. It is for this reason that the acetogenesis and the following step of methanogenesis takes place in a close special symbiosis to ensure that the hydrogen developed is directly used.
The propionic acid metabolism is often the time limiting step of anaerobic degradation (Schink, 1997).

Methanogenic bacteria are substrate specialists, which can only ferment a few organic compounds to methane. The energy gain from $\mathrm{H}_{2}$ and $\mathrm{CO}_{2}$ more advantageous, however about $72 \%$ of methane is developed from acetate during a single-stage process. Only $28 \%$ of methane is developed from $\mathrm{CO}_{2}$ and $\mathrm{H}_{2}$. A small amount of species can use other substrates such as formic acid and ethanol for methane synthesis (Smith and Mah, 1966).

\subsubsection{Environmental conditions and process quantities of anaerobic degradation}

The metabolic processes that proceed in the biogas fermenter require special environmental conditions (Table 4).

Table 4. Environmental requirements of hydrolysis/ acidification and methane fermentation (after Weiland, 2001)

Parameter

Temperature

$\mathrm{pH}-$ Value

C:N-Ratio

Solid matter content

Redox potential

Nutrient demand C:N:P:S

Trace elements
Hydrolysis/acidification

$$
25-35^{\circ} \mathrm{C}
$$

$$
5.2-6.3
$$$$
10-45
$$

$<40 \%$ dry matter

$+400--300 \mathrm{mV}$

$500: 15: 5: 3$

no specific requirements
Methane fermentation

mesophilic: $35-40^{\circ} \mathrm{C}$

thermophilic: $52-57^{\circ} \mathrm{C}$

$$
6.7-8.2
$$

$20-30$

$<30 \%$ dry matter

$<-250 \mathrm{mV}$

$600: 15: 5: 3$

essential: Ni, Co, Mo, Se

\subsection{Products of biogas production and utiliza- tion}

Biogas and fermentation residue are the end products of biogas production. In general the biogas is used for energetically. The fermentation residue can be used for different purposes.

\subsubsection{Biogas and its utilization}

Biogas from biogas production is denoted as raw biogas. It consists of $50-70 \%$ of $\mathrm{CH}_{4}, 30-50 \%$ of $\mathrm{CO}_{2}$ and small amounts of water vapour, $\mathrm{H}_{2} \mathrm{~S}, \mathrm{H}_{2}, \mathrm{O}_{2}, \mathrm{NH}_{3}$ and other trace gases. The further treatment of biogas is determined by the utilization purpose (Figure 5).

The advantage of biogas over other renewable energies like wind and solar energy is that it can be stored and its utilization is therefore independent from the location of biogas production. To feed biogas into the natural gas network or to use it as a fuel, it needs to be treated intensively. Afterwards it can be denoted as pure biogas

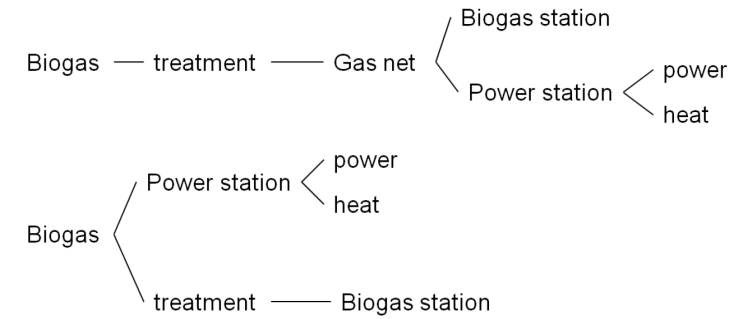

Figure 5. Utilization options of biogas

\subsubsection{Utilization of fermentation residue}

There are different utilization options for the fermentation residues from agricultural as well as waste material biogas plants. The quality of fermentation residue depend on the input substrate, process operation and degradation rate. Especially in agricultural plants it is common to use fermentation residues without a previous mechanical drainage. The fermentation residue is directly spread on agricultural areas as fertilizer during the vegetation period. By that the nutrient and carbon cycle can largely be closed. To be able to spread the fermentation residues an adequate amount of agricultural areas is required. If there are not enough agricultural areas the fermentation residue will be given to a manure market or is drained for further transport. 
The fermentation residue is given to a part or full treatment. During part treatment only a share of nutrients and carbon compounds is separated by draining. The objective of full treatment is to process the fermentation residues in a way that nutrients are available in high concentrations and that the purified waste water can be given to a waste water treatment plant, which is also called indirect discharge or direct discharge if given to receiving water after treatment. The treated clear water can furthermore be used as process liquid for fermentation. Figure 6 illustrates the general possibilities of treatment and utilization of fermentation residues.

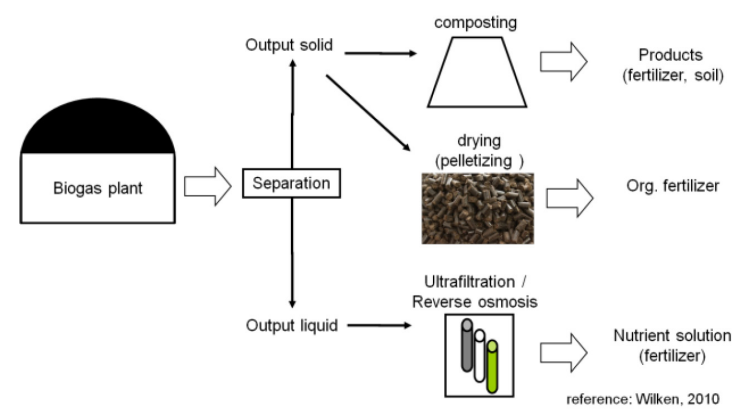

Figure 6. Treatment options of fermentation residues (Wilken, 2010)

\subsection{Emissions}

There are many discussions in literature on the amount of diffuse greenhouse relevant emissions produced by biogas plants. Recent studies show a very diverse view on that (e.g. Cuhls et al. (2009)). The parameters are TOC mass concentration $\left(\mathrm{kg} / \mathrm{m}^{3}\right)$ and mass flow for TOC $(\mathrm{kg} / \mathrm{h})$ and mass flow limit for ammonia $(\mathrm{kg} / \mathrm{h})$.

Organic carbon emissions (especially methane) develop under certain conditions e.g. during delivery of substrates; as odour emissions; as ammonia in the sewage storage; as methane in seepage water; as methane slip during gas treatment; as formaldehyde and methane in emissions from combined heat and power units; during stand still, maintenance and reparation of biogas plant; as odour, ammonia, methane and laughing gas during storage and spreading of fermentation residues (Daniel et.al, 2008).

Cuhls et al. (2009) have primarily examined their measurements with compost plants as well as with a few fermentation plants with downstream composting.

Up to now it was agreed that the methane slip from biogas plants is about $3 \%$. This value is considered for the climate balance of fermentation plants.

\section{Summary - Perspectives of biogas technology}

In comparison the energy consumption per capita in $\mathrm{Vi}$ etnam is only $20 \%$ of the energy use in Germany. In Germany about $5 \%$ of the energy demand per capita can be covered by biogas energy. In Vietnam, about $20 \%$ of the energy demand can be covered by biogas from agricultural residues and biowaste. There is another potential by the use of energy crops and industrial organic waste.
The country's livestock sector is growing, in 2010 the country counts more than 336 million of livestock animals (GSO, 2010).

Besides the building of new biogas plants the focus of investigations will be on the exploitation of other substrates, the closing of cycles and the reduction of emissions from biogas plants in both countries. By developing of modular technologies for biogas plants the investment and operation costs can be reduced. The improvement of the efficiency of combined heat and power units and the alternative utilization of biogas can increase the overall energy balance of plant operation. Regarding microbial matter conversion the enhanced disintegration of substrates, e.g. the improvement of biological availability through an intensified hydrolysis of hardly digestible materials, can fasten the overall process. Especially the biogas sector has a high development potential for the decentralized energy generation. However, utilization competition with other energy generating technologies exists. For further success possible credits for the fermentation products used as humus substitute are essential. The main advantage of biogas electricity is that it can be used as balancing energy in the future to compensate the natural disadvantages of wind and solar energy plants.

\section{References}

[1] Biogas handbook Bavaria 2011. http://www.lfu. bayern.de/abfall/biogashandbuch/index.htm, downloaded 2011-11-01 (in German).

[2] Bischofsberger, W., et al 2004. Anaerobic technology. Springer publishing, Munich, Colonia, Berlin. (in German).

[3] Cuhls, C., Mähl, B., Berkau S., Clemens, J. 2009. Determination of emissions in the utilization of biowaste. Final report under the authority of federal environmental agency, founding marks: 20633 326, Berlin (in German).

[4] Daniel, J., Postel, J., Scholwin, F., Vogt, R. 2008. Biogas plants: Technique and operation. Operation vol. A, C and D to the federal ministry of environment funding report „Optimization for a sustainable upgrade of the biogas production and -utilization in Germany“, founding marks: 0327544 http://www.ifeu.org/landwirtschaft/pdf/BMUBiogasprojekt\%202008-Materialband\%20C.pdf (in German).

[5] Dornack, C. 2010. Biogas from waste, agricultural residues and renewables - contribution of future energy supply. In: Waste-to-Energy in the city of tomorrow, ISBN: 978-604-911-001-6

[6] Intecus 2002. Sorting analyses of INTECUS GmbH. In: Waste in Saxony (in German). Series of regional authority for environment, agriculture and geology, working report, written by Institute for waste management and contaminated site treatment/ TU Dresden and INTECUS GmbH, unpublished.

[7] Fricke, K., Franke, H. 2002. Anaerobic treatment. In: ATV handbook - Mechanical and biological 
treatment of waste. Ernst and Son publishing, Berlin (in German).

[8] Fricke, K., Goedecke, H., Einzmann, U. 2003. The situation 2003. In: The future of separate collection of biowaste. Series of ANS 44, Orbit publishing, Weimar (in German).

[9] GSO, General Statistics Office of Vietnam 2010. Statistical Yearbook of 2010, Statistical Publishing House, 2011.

[10] Kaltschmitt, M., Hartmann, H. 2009. Energy from biomass. Fundamentals, techniques and treatment. Springer publishing, Berlin (in German).

[11] LfULG 2010. Potential study of arising and utilization of organic waste in Saxony. Series of regional authority for environment, agriculture and geology, module $\mathrm{C}$, by Institute for Waste Management and Contaminated Site Treatment/ Technische Universität Dresden and INTECUS GmbH, unpublished (in German).

[12] Man, T. D., Hien, L. T. 2006. Biomass Potentiality, Utilization and Status Development of Bio-fuel in Vietnam. Institute of Biotechnology. Vietnam Academy of Science and Technology, Vietnam.

[13] Stadtmüller, U. 2004. Fundamentals in Biowaste management. TK publishing. Karl ThoméKozmiensky Neuruppin (in German).

[14] Lootsma, A. and Raussen, T. 2008. Actual treatment options for pre-treatment and utilization of digested residues. In: Wiemer, $\mathrm{K}$ and Kern, M. (publisher). Use of bio- and recyclable matter. substantialenergetic III (in German).

[15] Raussen, T., Hack, K.-H. 2009. Kitchen- and food waste as co-substrate in biogas plants. Report on 3rd Biomass Forum Witzenhausen, pp. 75-86. http://www.witzenhausen-institut.de/downloads/ biomasseforum_2009_raussen_hack.pdf downloaded on 2012-03-09.

[16] Sahm, H. 1981. Biology of methane formation. Chem.-Eng.-Tech., 1981. 53(11): 854-863 (in German).

[17] Scholwin, F. 2006. Requirements on substrates for biogas plants. In: Book series of Forum of Waste Management and Contaminant Site Treatment, 46: 202 - 211. ISBN: ISBN-10: 3-934253-39-3.
[18] Schink, B. 1997. Energetics of syntrophic cooperation in methanogenic degradation. Microbiol Mol Biol. Rev. 61(2): 262-280.

[19] Schnapke, A. 2011. Utilization of biowaste from households for BtL-generation by wet-mechanical pre-treatment. Dissertation. TU Dresden, In: Book series of Forum of Waste Management and Contaminant Site Treatment, Vol.: 75, ISBN: 978-3-93425367-4.

[20] Schüsseler, P. 2004. Dry fermentation -Detection of needs in research and development, an introduction. In: Book series from Gülzow. Vol. 32 Dry fermentation.

[21] Smith, P.H. and Mah, R.A. 1966. Kinetics of acetate metabolism during sludge digestion. Appl Microbiol, 1966. 14(3): 368-71.

[22] Thrän, D., Witt, J., Hennig, C. Daniel-Gromke, J. Rensberg, N., Schwenker, A., Scheftelowitz, M., Wirkner, R., Vetter, A., Graf, T., Reinhold, G. 2009. Monitoring the impact of the Renewable Energy Sources Act (EEG) on the development of electricity from biomass. Report on DBFZ (in German).

[23] Federal Environmental Agency 1999. Nutrient release in composting and anaerobic digestion. New techniques for composting - recycling on agricultural land, Project 10.b part 1 and 2, book part II, Hamburg (in German).

[24] Vietnam Country report 2007. Annex 6: From ideas to action: clean energy solutions for Asia to address climate change. United States Agency for International Development (USAID).

[25] Weiland, P. 2001. Fundamentals of methane fermentation - Biology and substrates. VDI-report 1620: 19-29 (in German).

[26] Weiland, P. 2006. Energy from biomass, presentation on DAF conference Braunschweig, 25.-26. October 2006 (in German).

[27] http://www.agrarforschung.de/download/PPT_Weila nd.pdf, downloaded on 2011-15-03.

[28] WKO 2012. Country report Vietnam.

[29] http://wko.at/statistik/laenderprofile/lp-vietnam.pdf retrieved on 2012-07-10 (in German). 